D. N. Kozshevnikov ${ }^{1}$, V. N. Kozshevnikov ${ }^{2}$

${ }^{1}$ ZAO NPH VMP, 105, Amundsen Str., Ekaterinburg, Russia E-mail:dnk@fmp.ru

${ }^{2}$ Northumbria University, Newcastle, UK, E-mail:valery.kozhevnikov@northumbria.ac.uk

\title{
Combinatorial approach to the synthesis of substituted 1,2,4-triazines
}

This article describes a convenient and easy method of substitution of the nitrile group in 5-cyano-1,2,4-triazines with the aim of obtaining of libraries of substituted 1,2,4-triazines (about 500 compounds.

Key words: nucleophiles; nitrile group; 1,2,4-triazines.

Received: 02.03.2017; accepted: 10.03.2017; published: 14.04.2017.

Памяти Ю. Ю. Моржерина

Д. Н. Кожевников ${ }^{1}$, В. Н. Кожевников ${ }^{2}$

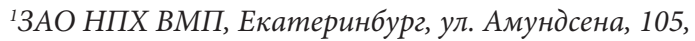
E-mail:dnk@fmp.ru

${ }^{2}$ Университет Нортумбрии, Ньюкасл, Великобритания,

E-mail: valery.kozhevnikov@northumbria.ac.uk

\section{Комбинаторный подход \\ к синтезу замещенных 1,2,4-триазинов}

Статья описывает удобный и легкий метод замещения нитрильной группы в 5-циано-1,2,4-триазинах с целью получения библиотеки замещенных 1,2,4-триазинов (около 500 соединений).

Ключевые слова: нуклеофилы; нитрильная группа; 1,2,4-триазины.

Поступило: 02.03.2017; принято: 10.03.2017; опубликовано: 14.04.2017.

(c) Kozshevnikov D.N., Kozshevnikov V.N., 2017

The reaction of substitution of the nitrile group in 5-cyano-1,2,4-triazines on the residues of the various nucleophiles occurs very easily both from the point of view of reaction conditions (requires neither an inert atmosphere, no pure solvents, no spe- cial reagents, no long heating) and allocation method (in most cases it is sufficient to dilute with water and filter the precipitate). Amines [1-4], alcohols [3] and $\mathrm{CH}$-active compounds [5] can act as nucleophiles. In principle, anilines also enter into this reac- 
tion, but do so very reluctantly only after prolonged heating [6].

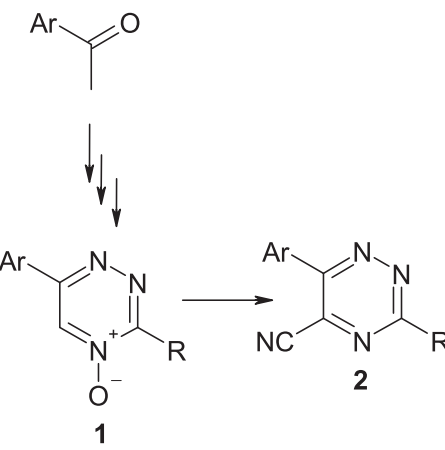

To obtain a library of substituted 1,2,4-triazines was proposed a strategy involving the synthesis of 1,2,4-triazine-4-oxides $\mathbf{1}$, their direct cyanation and subsequent substitution of cyano group in 5-cyano-1,2,4-triazines 2 . The simple synthetic procedures and available starting compounds (acetophenones, aldehydes and acetocyanohydrines) allowed to obtain in a 5-stages to 10 to 100 gram quantities of series of cyanotriazines 2 carrying different aliphatic, aromatic and heteroaromatic substituents in positions 3 and 6. Despite the originality of the leaving group (cyanide anion) its substitution allows to enter in triazine cycle the residues of ammonia, primary and secondary aliphatic amines (including, esters of amino acids, tryptamine, etc.), as well as aliphatic alcohols with the formation of 5-amino-1,2,4-triazines 3 and 5-alkoxy-1,2,4-triazines 4.

Реакция замещения нитрильной группы в 5-циано-1,2,4-триазинах на остатки различных нуклеофилов протекает чрезвычайно легко как с точки зрения реакционных условий (не требует ни инертной атмосферы, ни чистых
The ease of the reaction passing allowed to realize parallel synthesis of triazines $\mathbf{3}$

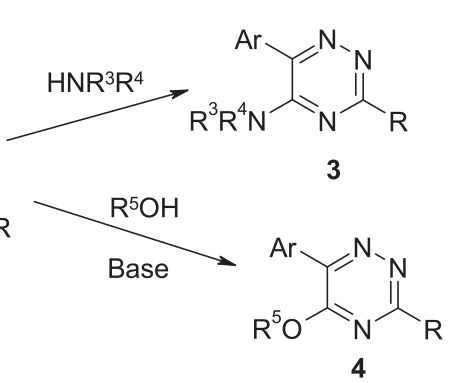

and 4. The standard procedure involved the addition of excess amine or alcohol (with the addition of base) to samples of 10-30 cyanotriazines $\mathbf{2}$ in the tubes or bottles. A short heating is necessary to accelerate dissolution of starting materials. The subsequent (a few hours) addition of water resulted in precipitation of the residues of desired products $\mathbf{3}$ and $\mathbf{4}$, which were only filtered. If desired, the products can be recrystallize from ethanol, but even without this the substituted triazines don't contain impurities (according to NMR spectroscopy). The reactions were with high yields close to quantitative.

As a result the unique reaction of substitution of cyano group was turned into a powerful tool that has been successfully used in the parallel synthesis to obtain a library of about 500 compounds 1,2,4-triazine series.

\section{In Russian}

растворителей, ни особых реагентов, ни длительного нагрева), так и способа выделения (в большинстве случаев достаточно разбавить водой и отфильтровать осадок). Нуклеофилами могут выступать амины [1-4], спирты [3] и СН-активные 
соединения [5]. В принципе, анилины также вступают в данную реакцию, но делают это весьма неохотно, лишь после длительного нагрева [6].

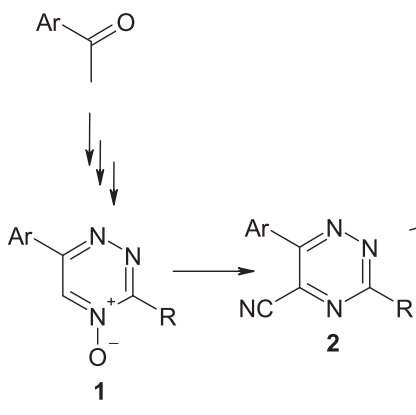

Для получения библиотеки замещенных 1,2,4-триазинов была предложена стратегия, включающая синтез 1,2,4-триазин-4-оксидов $\mathbf{1}$, их прямое цианирование и последующее замещение цианогруппы в 5-циано-1,2,4триазинах 2. Простые синтетические процедуры и доступные исходные соединения (ацетофеноны, альдегиды и ацетонциангидрин) позволили в 5 стадий получить в 10-100-граммовых количествах серию цианотриазинов 2, несущих различные алифатические, ароматические и гетероароматические заместители в положении 3 и $6 . \mathrm{He}$ смотря на своеобразность уходящей группы (цианид анион), ее замещение позволяет вводить в триазиновое ядро остатки аммиака, первичных и вторичных алифатических аминов (в том числе эфиров аминокислот, триптаминов и т. д.), а также алифатических спиртов с образованием 5-амино-1,2,4-триазинов 3 и 5-алкокси-1,2,4-триазинов 4.
Легкость протекания реакции позволила реализовать параллельный синтез триазинов 3 и 4. Стандартная процедура включала добавление из-

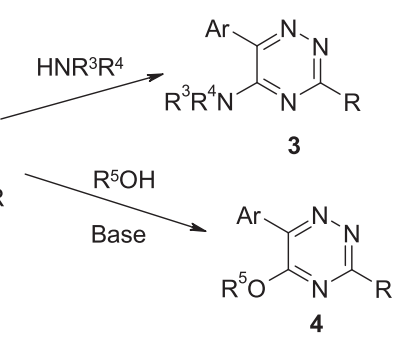

бытка амина или спирта (с добавкой основания) к навескам 10-30 цианотриазинов 2 в пробирках или бутыльках. Непродолжительное нагревание необходимо для ускорения растворения исходных веществ. Последующее (через несколько часов) добавление воды приводило к выпадению осадков желаемых продуктов 3 и 4, которые оставалось только отфильтровать. При желании продукты можно было перекристаллизовать из этанола, но и без этого замещенные триазины не содержали примесей (по данным ЯМР спектроскопии). Реакции с высокими выходами, близкими к количественным.

В результате уникальная реакция замещения цианогруппы была превращена в мощный инструмент, который был с успехом использован в условиях параллельного синтеза для получения библиотек - около 500 соединений 1,2,4-триазинового ряда.

\section{References}

1. Huang J. J. J. Org. Chem. 1985;50:2293-2298.

2. Rykowski A., Branowska D., Makosza M., Van Ly P. J. Heterocycl. Chem. 1996;33:15671571. 
3. Kozhevnikov V. N., Kozhevnikov D.N., Shabunina O. V., Kataeva N.N., Yushchuk S.A., Rusinov V.L., Chupakhin O. N. Russ. Chem. Bull. 2005;54:2187-2196.

4. Kozhevnikov D.N., Kozhevnikov V.N., Kovalev I. S., Rusinov V.L., Chupakhin O. N., Aleksandrov G. G. Russ. J. Org. Chem. 2002;38:744-750.

5. Prokhorov A. M., Kozhevnikov D. N., Rusinov V.L., Matern A. I., Nikitin M. M., Chupakhin O. N., Eremenko I. L., Aleksandrov G. G. Russ. J. Org. Chem. 2005;41:1702-1705.

6. Kopchuk D.S., Chepchugov N. V., Kovalev I. S., Santra S., Rahman M., Giri K., Zyryanov G. V., Majee A., Charushin V.N., Chupakhin O.N. RSC Adv. 2017;7:9610-9619.

\section{Cite this article as (как цитировать эту статью):}

Kozshevnikov D. N., Kozshevnikov V.N. Combinatorial approach to the synthesis of substituted 1,2,4-triazines. Chimica Techno Acta. 2016;4(1): 25-28. 